\title{
USE OF HUMIC ACIDS IN CATTLE PRODUCTION
}

\author{
MANIESON Victor Emmanuel, Saratov State Agrarian University named after N.I. Vavilov \\ KACHEPA UpileEmmanuella, Saratov State Agrarian University named after N.I. Vavilov \\ VASILIEV Alexey Alexeevich, Saratov State Agrarian University named after N.I. Vavilov
}

This present study was to investigate make propositions on the possible use of humic acids in cattle production. Study on the effects of a mixture of charcoal, sauerkraut juice and humic acidson cattles fed with GMO feeds containing glyphosates showed an increase in fecal gram-negative bacteria and a subsequent increase in general health of the cows. Also a study on the use of sauerkraut juice, charcoal and humic acid mixture on cows with chronic botulism, showed reduction in antibody levels of C.botilium $A B E$ and $C D$. At the end of a 24 week study the study animals were returned to normalcy and also had increased immunity.

Humate substances, or humic acids, are geological deposits in the earth's surface composed mainly of decaying plant and animal matter through the biological activities of microorganisms. Humates, based on solubility in acids and bases and by molecular weight, can be fractionated into three categories: fulvic acid, humic acid and humin[9]. In this report, we take a look at the use of humic acids in cattle production and husbandry based on the data and results of some research articles [10]. The effects of humates on the production of milk and beef.

On the research topic, Oral Application of Charcoal and Humic Acids Influence Selected Gastrointestinal Microbiota, Enzymes, Electrolytes, and Substrates in the Blood of Dairy Cows Challenged with Glyphosate in GMO Feeds[4], the following observations were made. Glyphosate is the most extensively used herbicide worldwide. Glyphosate is a highly effective, broad-spectrum herbicide that inhibits 5-enolpyruvyl shikimate 3-phosphate synthase (EPSPS), an enzyme of the shikimate pathway that is necessary to synthesize aromatic amino acids and other aromatic components in higher plants, algae, bacteria and fungi [1]. The herbicidal action is generated by chelating manganese required in the reduction of the flavin mononucleotide (FMN) cofactor of EPSPS[3]. The intensive use of glyphosate, especially in GMO forage and grain crops, has led to its wide-spread contamination of different ecosystems where it influences plants, microorganisms, animals and many components of the food chain. Reducing the activity of glyphosate in the gastrointestinal tract with binders or neutralizers could be a solution to remove this contamination. Mazzei and Piccolo found that glyphosate may spontaneously and significantly bind to soluble humic matter by non-covalent interactions at slightly acidic $\mathrm{pH}$ [7]. These results were confirmed by in vitro neutralizing assays with glyphosate sensitive enterococci Shehata et al., with different humic acid products [8]. Gerlach et al. Investigated the influence of oral applications of humic acids (WH67) and charcoal (another absorbent substrate) as well as a combination of charcoal and sauerkraut juice for treatment intervals of four weeks to Holstein Friesian dairy cows on one farm (380 cows) in Germany with clinical signs of chronic botulism. They reported that nearly all supplementations, except low doses of charcoal (200 g / animal and day) alone, led to a significant reduction of $\mathrm{C}$. botulinum $\mathrm{ABE}$ and CD antibody levels [5].
The study was initiated to investigate the influence of oral application of charcoal, sauerkraut juice and humic acids on specific gastrointestinal microbiota and selected enzymes, electrolytes, and substrates in the blood of dairy cows fed GMO feeds containing glyphosate. A total of 380 Schleswig Holstein cows suffering from symptoms of chronic botulism were fed sequentially with $400 \mathrm{~g}$ /animal charcoal daily for 4 weeks (weeks 1-4 of the study), $200 \mathrm{~g} /$ animal charcoal (weeks 5-10 of the study), $200 \mathrm{~g}$ charcoal and $500 \mathrm{ml}$ Sauerkraut juice/animal (weeks 11-14 of the study), $120 \mathrm{~g} /$ animal humic acids (weeks 15-18 of the study) $200 \mathrm{~g}$ charcoal and $100 \mathrm{~mL}$ Aquahumin/animal (weeks 1920 the of study), or $100 \mathrm{~g}$ charcoal and $50 \mathrm{~mL}$ Aquahumin (weeks 21-22 of the study) followed by 4 weeks without any supplementation. There was a significant reduction of glyphosate in urine following supplementation with a combination of $200 \mathrm{~g}$ charcoal plus either $500 \mathrm{~mL}$ sauerkraut juice or humic acid. From all of the parameters investigated in blood and urine, distinctive effects were only seen as a lack of manganese and cobalt and a significant reduction of creatinine excretion by urine. All other measured parameters such as creatine kinase (CK), alkaline phosphatase (AP), glutamate dehydrogenase (GLDH), glutamate oxaloacetate transaminase (GOT), and cholesterol, urea, and blood creatinine) were not significantly changed. A significant increase of fecal Gram-negative bacteria and enterococci were only seen at week 8 ( $200 \mathrm{~g}$ charcoal/d) and week 20 (200 g charcoal+100 mL Aquahumin). In conclusion, a charcoal-sauerkraut juice combination and humic acids reduced glyphosate excretion by urine and led to the improved health of animals

On the research topic, Oral Application of Charcoal and Humic acids to Dairy Cows Influences Clostridium botulinum Blood Serum Antibody Level and Glyphosate Excretion in Urine [5]. C. botulinum is an ubiquitous Gram-positive, spore forming, obligatory anaerobic bacterium that inhabits soil, dust and organic matter such as feces of animals and man, slaughterhouse wastes, residues of biogas plants, and bio-compost. It generates eight highly toxic neurotoxin isoforms (BoNT A-H) that are the most toxic substances known. In recent years, an increased frequency of a new form of bovine botulism has been observed. This form of botulism differs from regular food-born botulism by its slow and chronic development with various unspecific symptoms. This protracted form may develop when small, sub-lethal 
amounts of BoNT are taken up and/or absorbed over several days or are generated in the hind gut $[2,6]$.

Clinical symptoms of chronic botulism are most often peripartual cases with indigestion (constipation alternating with diarrhea), non-infectious acute laminitis, ataxia and stiff stilted gait, impossibility to get up (paralysis), apathy, engorged veins, positive venous pulse, edema in legs, udder, and dew-lap, retracted abdomen, forced respiration and unexpected death. The prevalence of $\mathrm{C}$. botulinum in cattle can be determined by detection of botulinum neurotoxins (BoNTs) and/or C. botulinum vegetative bacteria or spores in the gastrointestinal tract or organs (liver, kidney, lungs and muscles. The present study was initiated to investigate the influence of oral application of charcoal, sauerkraut juice and humic acids on chronic botulism in dairy cows. A total of 380 Schleswig Holstein cows suffering from chronic botulism were fed daily with $400 \mathrm{~g}$ /animal charcoal for 4 weeks (1-4 weeks of study), $200 \mathrm{~g} /$ animal charcoal (5-10 weeks of study), $120 \mathrm{~g} /$ animal humic acid (11-14s week of study), 200 $\mathrm{g}$ charcoal and $500 \mathrm{ml}$ Sauerkraut juice/animal (13-16 weeks of study), $200 \mathrm{~g}$ charcoal and $100 \mathrm{~mL}$ Aquahumin/ animal (15-18s week of study), $100 \mathrm{~g}$ charcoal and $50 \mathrm{~mL}$ Aquahumin (19-22 weeks of study) followed by 4 weeks without any supplementation.

Bacteriological and immunological parameters investigated included $\mathrm{C}$. botulinum and botulinum neurotoxins (BoNT) in faeces, C. botulinum ABE and $\mathrm{CD}$ antibodies, positive acute phase proteins (APPs) haptoglobin and LPS-binding protein (LBP) using serum ELISA, negative APP paraoxanase by its enzymatic activity and glyphosate in urine by ELISA. Neither BoNT nor C. botulinum was detected in feacal samples. From week six until four weeks before the end of the study, there was a significant reduction in antibody levels. All supplementation, except low doses of charcoal (200g / animal) alone, led to a significant reduction of $\mathrm{C}$. botulinum $\mathrm{ABE}$ and $\mathrm{CD}$ antibody levels. There also was a significant reduction of glyphosate in urine following supplementation with a combination of $200 \mathrm{~g}$ charcoal plus either $500 \mathrm{~mL}$ sauerkraut juice or humic acid. Haptoglobin, paraoxanase and LBP were significantly increased by the 24th week of the study. The positive APPs and C. botulinum antibodies were significant negative correlations. In conclusion, a charcoal-sauerkraut juice combination and humic acids could be used to control chronic botulism and glyphosate damage in cattle.
Conclusion. Based on the information above, I recommend the further research on the use of humid acids in neutralizing other food based poison as well as further research into the antibacterial and microbial properties of humic compounds.

\section{LITERATURE CITED}

1. Barry G., Padgette S.R. (1992) Glyphosate tolerant 5-enolpyruvylshikimate-3phosphate synthases. World Patent WO 92/04449.

2. Bohnel H., Schwagerick B., Gessler F. (2001) Visceral botulism--a new form of bovine Clostridium botulinumtoxication // J Vet Med A PhysiolPatholClin Med 48: 373-383.

3. Cerdeira A.L., Duke S.O. (2006) The current status and environmental impacts of glyphosate-resistant crops: a review.//J Environ Qual 35: 1633-1658.

4. Gerlach H., Gerlach A., Schrodl W., SchottdorfB., Haufe S.et al. (2014) Oral application of charcoal and humic acids to dairy cows influences Clostridium botulinum blood serum antibody level and glyphosate excretion in urine // J ClinicalToxicol 186: 2161-0495.

5. Gerlach H., Gerlach A., Schrodl W., Haufe S., Schottdorf B. (2014) Oral Application of Charcoal and Humic Acids Influence Selected Gastrointestinal Microbiota, Enzymes, Electrolytes, and Substrates in the Blood of Dairy Cows Challenged with Glyphosate in GMO Feeds. J Environ Anal Toxicol 4: 256. doi: 10.4172/2161-0525.1000256.

6. Kruger M., Grosse-Herrenthey A., Schrodl W., Gerlach A., Rodloff A. (2012) Visceral botulism at dairy farms in Schleswig Holstein, Germany: prevalence of Clostridium botulinum in feces of cows, in animal feeds, in feces of the farmers, and in house dust. Anaerobe 18: 221-223.

7. Mazzei P., Piccolo A. (2012) Quantitative evaluation of non-covalent interactions between glyphosate and dissolved humic substances by NMR spectroscopy. Environ SciTechnol 46: 5939-5946.

8. Shehata A.A., Kuhnert M., Haufe S., Kruger M. (2013) Neutralization of the antimicrobial effect of glyphosate by humic acid in vitro // J chemosphere 10: 258-261.

9. Stevenson F.J. (1982) Humus Chemistry, Wiley, N.Y.

10. Vasiliev A.A. Value, theory and practice of using humic acids in animal husbandry / A.A., Vasiliev, A.P. Korobov, S.P. Moskalenko, L.A. Sivokhina, M.Yu., Kuznetsov // Agrarian Scientific Journal, No. 1, 2017, P. 3-6.

Manieson Victor Emmanuel, student, Saratov State Agrarian University named after N.I. Vavilov. Russia.

Kachepa Upile Emmanuella, student, Saratov State Agrarian University named after N.I. Vavilov. Russia.

Vasiliev Alexey Alexeevich, Doctor of agricultural sciences, Professor, Head of the chair "Feeding, Zoohygient and Aguaculture",Saratov State Agrarian University named after N.I. Vavilov. Russia.

Keywords: agriculture; humic acids; feeding; cattle production; immune system.

\section{ПРИМЕНЕНИЕ ГУМИНОВЫХ КИСЛОТ В СКОТОВОДСТВЕ}

Маниесон Виктор Эммануэль, студент 5-го курса, Саратовский государственный аграрный университет имени Н.И. Вавилова. Россия.

Качепа Упиле Эммануелла, студент 5-го курса, Саратовский государственный аграрный университет имени Н.И. Вавилова. Россия.

Васильев Алексей Алексеевич, $\partial-p$ c.- $x$. наук, проф., зав. кафедрой «Кормление, зоогигена и аквакультура», Саратовский государственный аграрный университет имени Н.И. Вавилова. Россия.

Ключевые слова: сельское хозяйство; гуминовые кислоты; кормление; скотоводство; иммунная система.

Представлены данные о возможном использовании гуминовых кислот в производстве крупного рогатого скота. Изучено влияние смеси древесного угля, сока квашеной капусты и гуминовых кислот на усвояемость кормов, содержащих глифосаты. Исследование данной смеси показало снижение уровня антител C. botilium ABE и CD у коров с хроническим ботулизмом. В конще 24-недельного опыта исследуемые жсиотные вели нормальный образ жизни, отличались повышенным иммунитетом. 